\title{
Yleisen lapsilisäjärjestelmän synty Ruotsissa ja Norjassa
}

Kirjoittanut Armas Nieminen.

\section{Johdanto.}

Seurattaessa perheiden taloudellista tukemista tarkoittavan yhteiskunnallisen toiminnan kehitystä yhä täydellisemmäksi sosiaalipoliittiseksi järjestelmäksi Ruotsi on väestöpolitiikan emämaan Ranskan ohella sopiva tutkimuskohde. Läntisessä naapurimaassamme tällaisen toiminnan tarve onkin tunnettu. polttavaksi, kun siellä väestökriisi, väkiluvun tulevan vähenemisen uhka, kehittyi nopeasti erittäin vakavaksi, niin että esim. vuoden 1935 tienoilla lapsia syntyi vain noin $3 / 4$ siitä määrästä, mikä olisi ollut tarpeen, jotta väestö - ellei muuttoliikettä oteta huomioon - pitkällä tähtäimellä katsoen jatkuvasti olisi pysynyt suuruudeltaan ennallaan, joten tässä suhteessa vielä huolestuttavampia lukuja voitiin esittää vain Itävallasta ja Virosta. ${ }^{1}$ Kun täten selitettävään väestöpolitiikan kipeään tarpeeseen ovat yhtyneet yhteiskunnallisille uudistuksille suo- tuisat edellytykset, olojen suurempi rauhanomaisuus kuin muualla Euroopassa, väestön korkean sivistystason ja kansanvaltaisen valtiollisen järjestelmän aikaansaama uudistusystävällisyys sekä maan vauraus, on luonnollista, että Ruotsin väestöpolitiikka eli perhepolitiikka (familjepolitik), mitä nimitystä siellä on ryhdytty yleisesti käyttämään, on kehityksessään ehtinyt varsin pitkälle. ${ }^{2}$ 
Siitä tieteellisestikin merkittävästä sosiaalisesta ja sosiaalipoliittisesta selvittelytyöstä, mitä Ruotsin väestöpoliittisten uudistusten valmistelun yhteydessä valtion toimesta on suoritettu, ovat todistuksena Ruotsin valtion virallisessa julkaisusarjassa, Statens offentliga utredningar, ilmestyneet väestökysymyksen eri puolia monipuolisesti käsittelevät komiteanmietinnöt ja selvitykset. Näistä on 17 (16 painosta ilmestynyttä) julkaissut vuosina 1935-1938 toiminut väestökomitea, ns. befolkningskommissionen, ja 19 vuosina 1941 -1946 nykyisen pääministerin Tage Erlanderin johdolla ja Gustav Möllerin ollessa sosiaaliministerinä työskennellyt toinen väestökomitea, ns. 1941 års befolkningsutredning*, jonka tärkeimpänä tehtävä oli yleisen lapsilisäjärjestelmän valmistelu.

Kun meillä 1948 lapsilisäuudistusta toteutettaessa otettiin mallia Ruotsista ja kun siellä suoritetun väestöpoliittisen suunnittelutyön tulokset siis ovat koituneet meidänkin maamme hyväksi (ks. edellistä kirjoitusta), on seuraavassa tehty selkoa sikäläisen lapsilisäjärjestelmän synnystä. Koska uudistus kuitenkin toteutettiin Norjassa jo aikaisemmin ja kun Ruotsi tässä suhteessa on saanut vaikutteita vuorostaan läntisestä naapurimaastaan, on tässä kirjoituksessa Ruotsin yleisen lapsilisäjärjestelmän syntyä koskevaan esitykseen liitetty selonteko myös Norjassa tapahtuneesta vastaavasta kehityksestä. Edellä esitetyistä syistä ja kun käytettävissä ollut lähdeaineisto Ruotsin osalta on ollut täydellisempää kuin Norjan, on kuitenkin uudistuksen syntyä Ruotsissa selostettu perusteellisemmin kuin Norjassa.

\section{Perhekustannusten tasauksen perustelut.}

Koska lapsilisän antaminen perheille on perhekustannusten tasauksen osakysymys, so. pyrkimyksen siirtää lapsen elättämisestä ja kasvattamisesta aiheutuvat menot, lapsenkasvatus- eli perhekustannukset (ruots. barnkostnader), yhä enemmän vanhemmilta yhteiskunnan yhteisesti kannettavaksi, joudutaan lap-

* Tätä komiteaa tarkoitẹtaan seuraavassa Ruotsin väestökomitealla. 
silisäjärjestelmälle perusteluja esitettäessäkin perustelemaan perhekustannusten tasausta. Täten ovat mietinnöissään ${ }^{3}$ menetelleetkin yleistä lapsilisäjärjestelmää Ruotsissa ja Norjassa valmistelleet komiteat, Ruotsin edellä mainittu toinen väestökomitea ja Norjan vuosina 1934-1937 lapsilisäkysymystä käsitellyt komitea.

Molemmat komiteat todistelivat elinkustannustutkimuksiin nojautuen, että vanhempien on lasten huoltamisen vuoksi kieltäydyttävä sellaisten omien elämäntarpeiden tyydyttämisestä, joihin heillä muuten olisi mahdollisuus, ts. että perheen kasvulla on sen elintasoa alentava vaikutus. Niinpä esim. Ruotsin kaupungeissa ja teollisuuskeskuksissa niissä työläispiireissä, joiden keskuudessa perheen vuositulot olivat $3.000-5.000$ kruunua, vuosina 1932 - 1934 toimitetun, perheiden vuoden kuluessa pitämiin tilikirjoihin perustuvan elinkustannustutkimuksen ${ }^{4}$ mukaan neljän tai useamman lapsen perheissä, joissa vanhin lapsi oli 14 vuotta vanhempi, ravintomenot olivat vain $81 \%$, vaatetusmenot $10 \%$ ja jalkinemenot $120 \%$ suuremmat kuin lapsettomilla pariskunnilla, mutta esim. asuntomenot olivat ensiksi mainituissa perheissä vain $53 \%$, sanomalehtiin, kirjoihin ym. kuluvat menot $49 \%$ sekä terveydenhoidon, pesun ja silityksen aiheuttamat kulut $78 \%$ niiden määrästä lapsettomissa avioliitoissa. Täten siis perheellisten elintaso oli paljon matalampi kuin yksinään elävien. Kun mainituissa lapsiperheissä 43,8 \% menoista kului kaikkein välttämättömimpään, ravintoon, vastaava luku lapsettomissa perheissä oli vain $27,2 \%$. Tällöin on tosin otettava huomioon, että ravinnon kulutus muodostaa lasten kokonaiskulutuksesta suuremman osan kuin aikuisten. Kuluttajayksikköä, so. täysi-ikäisen miehen kulutusta kohden laskettuna ravintomenot olivat neljän tai useamman lapsen perheissä vain vähän yli puolet siitä, mitä ne olivat lapsettomissa avioliitoissa.

Tätä tosiasiaa, että perheen elintason kohottamispyrkimys ja lasten kasvattaminen ovat keskenään ristiri i da s s a, komiteat pitivät epäkohtana ja katsoivat, että yhteiskunnan on koetettava tätä ristiriitaa heikentää tasaamalla perhekustannuksia. Näin ensinnäkin yhteis- 
kunnan perustan, väestön säilyttämisen vuoksi, siis vä e s t öpoliittisista syistä. Pidettiin näet ilmeisenä, että juuri tämä perheen kasvun elintasoa alentava vaikutus on ollut olennaisena syynä syntyvyyden tarkoitukselliseen rajoittamiseen, mikä on aiheuttanut väestökriisin.

Ruotsin väestökomitean toimesta suoritettiin vuosina $1942-$ 1945 kiertokyselymetodia käyttäen edustava tutkimuskin 353:n vielä lisääntymiskykyisen göteborgilaisen perheen suhtautumisesta syntyvyyden säännöstelyyn ja väestöpoliittisiin toimenpiteisiin. $^{5} \quad$ Se syntyneisyyden lisäys, mikä tämän tutkimuksen mukaan tulisi olemaan seurauksena, jos taloudelliset seikat eivät lainkaan vaikuttaisi lasten lukumäärän rajoittamiseen, olisi noin $40 \%$. Tällainen tulos ei tietenkään ole sellaisenaan yleistettävissä, mutta se täsmällistää käsitystä, että taloudellisilla seikoilla on oma merkityksensä syntyvyydén rajoittamisessa.

Ruotsin väestökomitea, jonka asettamisen varsinaisena aiheena olikin ollut pelko väenlisäyksen lakkaamisesta, piti väestöpoliittisia näkökohtia kaikkein tärkeimpinä. Erityisesti se vetosi syntyneisyyden alenemisesta johtuvaan työkykyisten ikäluokkien kutistumiseen ja tästä seurauksena olevaan työvoiman puutteeseen. Tällaisia näkökohtia tähdentäessään komitea kuitenkin samalla torjui huomion kiinnittämisen liian yksipuolisesti näihin ja korosti, että lapsiluvun lisäykseen pyrkivän väestöpolitiikan ehdottomana edellytyksenä on oleva, että lapsilla tulee olemaan entistä onnellisemman elämän mahdollisuudet.

Myöskään väestön la a tukysymys ei jäänyt huomiota vaille. Niinpä Ruotsin sosiaaliministeri Möller totesi antaessaan váltiopäiville lapsilisäesityksen, että yhteiskunnan tulevalle kehitykselle on mitä merkittävintä, millaisissa olosuhteissa lapset, joiden huostaan yhteiskunta tulevaisuudessa on joutuva, kasvavat ja kehittyvät. Samoin Ruotsin väestökomitea oli asettanut yhteiskunnan velvollisuudeksi huolehtia siitä, että lapset eivät joudu elämään elämäänsä kurjissa fyysillisissä ja psyykillisissä olosuhteissa ja että lasten elättämisen taakka ei paina perheen elintasoa siedettävää alemmaksi. Siis myös ah- 
taammassa mielessä sosiaalipoliittisten näkökohtien huomioon ottamista tehostettiin.

Kun väestön ja lasten merkitystä yhteiskunnalle näin tähdennettiin, jouduttiin korostamaan myös sitä, että huolenpito lapsista on koko yhteiskunnan asia. Perhekustannukset olisi näin ollen jaettava kaikkien kansalaisten kannettavaksi samanlaisten perusteiden mukaan kuin kysymyksen ollessa yleensäkin yhteisistä asioista johtuvista kustannuksista. Samoja näkökohtia myös Norjan lapsilisäkomitea voimakkaasti tähdensi ja huomautti, että oli ohi se aika, jolloin huolenpidon lapsista voitiin katsoa kuuluvan yksinomaan vanhemmille.

Painavampana kuin yhteiskunnan edun sanelemia väestöpoliittisia perusteluja Norjan komitea kuitenkin piti individualistisia o i ke u den m u ka is u usnäkökohtia - tässä maassahan ei väestökriisiin ollutkaan kiinnitetty niin suurta huomiota kuin Ruotsissa - mutta kyllä Ruotsinkin komitea ne voimakkaasti toi esiin. Edellä mainitun Göteborgissa toimitetun tutkimuksen mukaan yhä leviävä suopea asennoituminen valtion toimesta suoritettaviin perheen taloudellisiin tukemistoimenpiteisiin ei perustunutkaan niin paljon väestöpoliittisiin näkökohtiin kuin käsitykseen sellaisen olotilan epäoikeudenmukaisuudesta, että ne, jotka huolehtivat yhteiskunnalle perustavan tärkeästä lasten vaalimisesta ja kasvattamisesta, joutuvat tämän vuoksi uhraamaan taloudellisesta hyvinvoinnistaan. Oikeudenmukaisuusnäkökohtien siis erityisesti sodanaikaisissa vaikeuksissa katsottiin vaativan sellaisten olosuhteiden luomista, että kansalaisten elintaso ei jäisi riippuvaiseksi siitä, elättävätkö he lapsia vai eivät.

Väestöpoliittisilla ja oikeudenmukaisuusnäkökohdilla perusteltu perhekustannusten tasaus tulisi täten merkitsemään ihmisten olojen tasoittamista siihen nähden, mikä vaikutus perhesuhteilla on heidän elintasoonsa. Ruotsin väestökomitea totesikin, että tällainen uudistus oli muuttava tulojen jakaantumisen yhteiskunnassa sellaiseksi, että etenkin lapsettomat, mutta myös yhden kahden lapsen perheet tulisivat entistä suuremmassa määrässä osallistumaan koko kansan yhteisen nousevan polven 
huoltamiseen, kun taas kolmen lapsen tai sitä suurempien perheiden taakka tässä suhteessa kevenisi. Samoin joutuisivat kansalaiset sinä aikana, jolloin heidän lapsensa jo ovat kasvaneet aikuisiksi, veronmaksajina osallistumaan perhekustannusten tasaukseen.

Kehitys Ruotsissa luontoisavustuksista rahasuorituksiin.

Kun perhekustannusten tasauksen aatetta Ruotsissa 1930luvun puolivälissä erittäinkin Alva ja Gunnar Myrdalin selvittelytyön ${ }^{6}$ jälkeen alettiin käytännöllisessä yhteiskuntapolitiikanssa toteuttaa, suuntautui tämä uudistustyö aluksi ns. luontoissuorituslinjalle: pyrittiin siihen, että yhteiskunta ottaisi välittömästi tyydyttääkseen osan lasten tarpeista. Yhteiskunnan tuki perheille oli täten annettava »luonnossa», tarvikkein tai palveluksin. Tällaisten avustusten puolesta ensimmäinen väestökomitea esitti varsinkin neljä näkökohtaa: 1) Tällainen järjestelmä tulee yhteiskunnalle halvemmaksi kuin raha-avustusten antaminen; 2) tällaista avustusmuotoa käyttäen saadaan varmimmat takeet siitä, että avustukset todella koituvat lasten hyväksi eivätkä mene muihin tarkoituksiin; 3) kun yhteiskunta voi määrätä, millaisena avustus annetaan, voidaan perheiden kulutusta ohjata entistä terveempään suuntaan; ja 4) lasten tarpeet voidaan tyydyttää entistä taloudellisemmin ja tarkoituksenmukaisemmin, kun yhteiskunta voi tarvikkeiden tuotannossa toteuttaa standardisointia ja entistä tehokkaampaa valvontaa. ${ }^{7}$

Luontoisavustuslinjalla toteutettinkin sitten Ruotsissa 1930-luvulla pitkä väestöpoliittisten u udistusten sarja. ${ }^{8}$ Vuonna 1935 ryhdyttiin ensin vähävaraisille lapsirikkaille ns. perheasuntotaloissa (barnrikehus) asuville perheille antamaan asuntoavustuksia (familjebidrag). Lapsen syntymästä vanhemmille aiheutuvien kustannusten korvaaminen, joka vuodesta 1931 saakka oli ollut käytännössä vain kaikkein köyhimpiin äiteihin nähden, taas päätettiin vuon- 
na 1937 laajentaa yleiseksi ottamalla käytäntöön erilaisia äitiysavustuksen muotoja: äidinapu (mödrahjelp), äitiysraha (moderskapspenning) ja äitiysapu (moderskapshjelp). Sosiaalilääkinnöllisten uudistusten sarjassa seurasivat sitten vuonna 1937 äitiys- ja lastenhoidonneuvonnan, seuraavana vuonna periaatteessa ilmaisen synnytyshuollon sekä vuonna 1938 maksuttoman hammashoidon alku, ja 1939 ryhdyttiin jakamaan ilmaiseksi suojalääkeaineita raskaille ja imettäville naisille sekä koululaisille. Vuosina 1940-1947 vähävaraiset, siis ennen kaikkea suuret perheet, saivat hinnanalennusta lihasta ja maidosta. Toisen väestökomitean työn tuloksena näitä toimenpiteitä on jatkettu: vuonna 1944 alkoi maksuttoman kouluterveyden- ja -hammashoidon yleistäminen kaikkia oppilaita koskevaksi, samana vuonna alettiin valtion toimesta avustaa lastentarhojen ja päiväkotien ylläpitoa sekä avustaa ja laajentaa sosiaalista kotiaputoimintaa, vuonna 1946 päätettiin tehdä ilmaiset kouluateriat täysin yleisiksi ja ottaa käytäntöön ilmaiset koulukirjat ja muut koulutarvikkeet kaikille kansakoulun oppilaille, samana vuonna myös ryhdyttiin yleistämään äitien ja lasten ilmaisia kesälomamatkoja ja maksutonta kesäloman viettoa tarkoittavia järjestelyjä, ja seuraavana vuonna uusittiin ja laajennettiin perheasuntoavustusjärjestelmää (ks. s. 55).

Pyrittäessä täten perhekustannusten tasaukseen luontoissuorituksin kävi kuitenkin yhä selvemmäksi, että lapsista vanhemmille koituvat kustannukset vain osittain voidaan korvata sillä tavoin, että yhteiskunta välittömästi huolehtii lasten tiettyjen tarpeiden tyydyttämisestä esim. kollektiivijärjestelyin. Kaikkien sosiaalipoliittisten toimenpiteiden, joilla voitiin katsoa olevan väestöpoliittista merkitystä, arvioitiinkin Ruotsissa toisen maailmansodan alkaessa tuottavan valtiolle vain 30 miljoonan kruunun kustannukset. Perheille vapaasti käytettäväksi annettava taloudellinen tuki koituisi nimenomaan kotien hyväksi, joiden katsottiin jääneen liiaksi varjoon kollektiivisten tukitoimenpiteiden rinnalla. Näin ollen toisen väestökomitean mielestä se kanta, että perhekustannusten tasauksessa olisi käytettävä etupäässä vain luontoisavustuslinjaa, oli yksipuolinen. Myöskään 
komitea ei katsonut yleistä lapsilisäjärjestelmää suunniteltaessa Ruotsin olosuhteissa tarkoituksenmukaiseksi omaksua sellaista jatkuvaa luontoissuoritusjärjestelmää, mitä Suomessa perhelisälain toimeenpanossa vuodesta 1943 alkaen oli noudatettu ja mihin komitean sihteeri kävi täällä tutustumassakin.

Täten Ruotsin toinen väestökomitea päätyi valmistelemaan sellaista järjestelmää, jonka vallitessa lasten huoltamisen ja kasvattamisen aiheuttamien kustannusten korvaamiseksi jatkuvasti suoritettaisiin heidän huoltajilleen $\mathrm{rah}$ a s a maksettavia lapsiavustuksia eli lapsilisiä (barnbidrag). Laatimansa ehdotuksen yleisestä lapsilisäjärjestelmästä komitea esitti 19. 1. 1946 allekirjoittamassaan mietinnössä ${ }^{3}$, joka samalla sisälsi yhtenäisen kokoavan esityksen kaikista komitean suunnittelemista väestöpoliittisista toimenpiteistä.

Kaikissa komitean esityksestä annetuissa lausunnoissa ${ }^{9}$ suhtauduttiin periaatteessa myönteisesti uudistuksen toteuttamiseen, mutta joissakin tuotiin myös esille epäilyksiä raha-avustusjärjestelmän tarkoituksenmukaisuudesta. Tähdennettiin luontoisavustusjärjestelmän etuja etenkin köyhempään väestöön nähden, mille kansanosalle uudistuksen toteuttaminen olisikin kaikkein välttämättömintä, epäiltiin perheiden kykyä käyttää saamansa lapsilisät taloudellisesti, huomautettiin, että lapsirikkaissa perheissä saattavat yllättävän suurilta tuntuvat lapsilisävarat helposti kulua aivan toisarvoisiin tarkoituksiin ja vaikuttaa perheenhuoltajan työhalua heikentävästi ja suositeltiin jo aikaisemmin luontoissuorituslinjalla toteutettujen uudistusten edelleen kehittämistä.

Tähdentäen vaikeutta tehdä kollektiivijärjestelyt niin laajoiksi, että niiden perhekustannuksia tasaava merkitys olisi kaikille yhtä suuri, ja katsoen raha-avustusten merkitsevän todella huomattavaa tasausta hallitus kuitenkin asettui puoltamaan raha-avustuslinjaa. On sellaisia tarpeita, jotka ovat samoja kaikille, mutta on eri perheille erilaisiakin tarpeita. Sen vuoksi yhteiskunnan on tuettava perheitä sekä raha- että luontoissuorituksin. Edellisten voi sanoa muodostavan perustan perhekustannusten tasauksessa. Niihin liittyvät sitten tukitoimen- 
piteet erityisissä tilanteissa, kuten raskauden aikana ja lapsen syntyessä tai esim. vuokran ja elintarvikkeiden hintojen alennukset.

Komitean mietinnöstä käydyssä keskustelussa kiinnitettiin myös huomiota erääseen raha-avustussuoritusten varjopuoleen, nim. siihen, että tällainen järjestelmä voi lisätä edellytyksiä harkitsemattomaan suvun lisäykseen, mikäli vanhemmat ovat asosiaalisia, psyykillisesti jälkeen jääneitä tai muuten sielullisesti vajaakykyisiä. Tällaiset suuret perheet muodostavat jo ennestäänkin vakavan sosiaalisen kysymyksen. Huomautettiin, että joissakin tapauksissa voitaisiin lapsilisän saannin $\in$ hdoksi asettaa sterilisoimistoimenpiteet ja että avustusten käytön valvontaan olisi joka tapauksessa kiinnitettävä huomiota. ${ }^{10}$ Toisaalta vastattiin, että kahden tai useamman lapsen perhe saa jo ennestään valtiolta luonnossa perheasuntoavustuksena ja ilmaisina kouluaterioina n. 260 kruunua lasta kohden, ja nyt ehdotetaan sama määrä rahana annettavaksi. ${ }^{11}$

Siitä seikasta, että Ruotsissa lapsilisäuudistuksen kaikissa vaiheissa suunniteltiin yleistä koko kansaan ulottuvaa järjestelmää, seurasi myös, että perhepalkkausjärjestelmä, jonka vallitessa työnantajat palkan lisänä suorittaisivat työntekijöilleen perhekustannusten tasausta, komiteassa alun alkaen hylättiin. Myös omaan lukuunsa työskentelevien samoinkuin työttömienkin oli päästävä lapsilisistä osallisiksi. ${ }^{12}$

Luonteenomaista uudistuksen valmistelulle Ruotsissa oli, että siellä katsottiin valtiolle mahdolliseksi rahoittaa uudistuksen säännöllisistä tulolähteistään. Mikäli tästä seikasta ilmeni epäilyksiä, ajateltiin tällaisen rahoittamisen käyvän päinsä ainakin siinä tapauksessa, että järjestelmä rajoitettaisiin koskemaan vasta järjestyksessä perheiden toisia ja sitä seuraavia lapsia. Tähänkään rajoitukseen ei kuitenkaan tarvinnut turvautua. Lain tuottamien kustannusten arvioitiin lain voimassa oloajan ensimmäisen vuosipuoliskon 1.1.-30.6. 1948 aikana nousevan 208 milj. kruunuun. Kun kuitenkin lapsivähennykset valtion tuloverotuksessa lapsilisäjärjestelmän käytäntöön ottamisen yh- 
teydessä poistettiin, tulivat valtion verotulot nousemaan, arviolta n. 140 milj. kruunua vuodessa, ja näin ollen perheelliset tulivat noin 1.600.000 lapsestaan valtiolta saamaan perhekustannusten tasausta vuodessa n. 275 milj. kruunua enemmän kuin ennen.

Esityksensä valtiopäiville laiksi yleisistä lapsilisistä Ruotsin hallitus antoi huhtikuussa 1947, ja tultuaan hyväksytyksi valtiopäivillä laki tuli voimaan 1. 8. 1947, kuitenkin niin, että lapsilisiä alettiin suorittaa vasta vuoden 1948 alusta lukien. ${ }^{13}$ Samana päivänä kuin yleisistä lapsilisistä annettiin myös laki erityisistä lapsilisistä (särskilda barnbidrag) leskien ja invaliidien ym. lapsille ja laki avustuksista leskille, joilla on lapsia. ${ }^{14}$ Erityisiä lapsilisiä oli alettu suorittaa vuonna 1938. Sotapalveluksessa olleiden perheille oli maksettu perhelisiä (familjebidrag). Lapsilisät (barntillägg) ovat Ruotsissa käytännössä myös sairaūsvakuutuksessa ja työttömyysvakuutuksessa.

\section{Kehitys Norjassa.}

Kun Ruotsissa 1930-luvun puolivälissä vavahduttavasti herättiin huomaamaan väestökriisin perustava merkitys yhteiskunnalle kokonaisuudessaan ja kun tästä tosiasiasta havaittiin seurauksena olevan välttämättömyyden ryhtyä syvällisiin yhteiskunnallisiin uudistuksiin, näyttää Norjassa väestöpolitiikan lähtökohtana olleen käytännöllisempi ja rajoitetumpi kysymys, perheellisten toimeentulon tiukentuminen, mikä herätti pyrkimyksiä sosiaalisen turvallisuuden toteuttamiseksi heihin nähden niin, ettei heidän elintasonsa kohtuuttomasti alenisi. Jo ennen ensimmäistä maailmansotaa ja varsinkin sen aikana perheiden taloudellisen aseman vaikeutuminen oli useissa maissa, mm. Norjassa, aiheuttanut rajoitetun perhepalk ka usjärjestelmän synnyn. Etupäässä valtion ja kunnan virkamiehille oli alettu maksaa palkanlisää heidän elätettävänään olevista lapsista. Tällä linjalla, siis raha-avustuslinjalla kehitys Norjassa jatkuikin. ${ }^{15}$ 1930-luvun alkupuo- 
lella esitettiin julkisessa keskustelussa sanomalehdistössä ja valtiopäivillä oikeudenmukaisuusnäkökohtiin sekä pyrkimykseen saada korkea pikkulasten kuolleisuus alenemaan perustuvia vaatimuksia siitä, että yhteiskunnankin velvollisuus on osallistua perhekustannuksiin. Perheellisten taloudellisen aseman horjumista vaadittiin torjuttavaksi tavalla tai toisella siten, että perheen tulot jollakin tavalla tehtäisiin riippuvaisiksi sen huoltovelvollisuuden laajuudesta. 30. 10. 1934 hallitus sitten asettikin G. Wiesenerin puheenjohdolla komitean tutkimaan kysymystä, voitaisiinko saada aikaan palkkojen järjestely, jossa lasten edut olisi entistä paremmin otettu huomioon esim. siten, että palkanmaksun yhteydessä suoritettaisiin jokaisesta lapsesta lisäpalkkaa. Komitean oli kuitenkin myös tutkittava, voitaisiinko muillekin kuin palkannauttijoille turvata tällaiset edut. Tämän komitean asettamisessa siis jo ilmeni käsitys siitä, että perhepalkkausjärjestelmällä ei perhekustannusten tasausta saatettaisi toteuttaa, koska sitä voitaisiin soveltaa vain palkannauttijoihin. Komitean työn aikana tämä täysin selvisikin, ja 10. 10. 1937 allekirjoittamassaan em. mietinnössä ${ }^{3}$ komitean enemmistö esitti toteutettavaksi yleisen lapsilisäjärjestelmän. Yksi jäsen kahdeksasta sensijaan puolsi rajoitetua perhepalkkausjärjestelmää. Lapsilisistä komitea käytti nimitystä barnetrygd, lapsivakuutus. Ehdotuksen mukaan oli vanhemmille perhekustannusten korvaamiseksi maksettava »korkoa lapsista», barnerenter, mikä luonteeltaan kuitenkin olisi ollut aivan tavallista lapsilisää.

Kuten komitean omaksuma lapsilisän nimityskin jo osoittaa, oli ajateltu uudistuksen rahoittamista $v$ aku u tusjärjestelmä ä käyttäen, niin että lisän saajat vakuutusmaksuja suorittamalla kokoaisivat tarvittavat varat. Sairausvakuutuksen yhteydessä maksut eivät olisi vakuutetuille käyneet kovin rasittaviksi, kun myös työnantajat olisivat tällöin joutuneet vakuutusmaksuihin osallistumaan. Tämä rahoituskeino ei kuitenkaan käynyt päinsä, koska sairausvakuutuksen alaisena oli vain osa kansasta, joten lapsilisäjärjestelmä ei olisi täten tullut yleiseksi, jollaisen välttämättömyydestä käsitys komiteassa kui- 
tenkin oli vahvistumistaan vahvistunut. Vanhuusvakuutuksen yhteydessä yleisen lapsilisäjärjestelmän toteuttaminen sen sijaan olisi hallinnollisesti hyvin käynyt päinsä, sillä tämä järjestelmä koski kaikkia kansalaisia. Kun tähän vakuutusmuotoon kuitenkin yleisesti oltiin varsin tyytymättömiä ja kun lapsilisäjärjestelmän kytkeminen tähän olisi suuresti lisännyt vakuutusmaksujen määrää, ei komitea katsonut tarkoituksenmukaiseksi käyttää tätä rahoitusmenetelmää. Näin ollen tultiin siihen tulokseen, että uudistus oli rahoitettava verotuksella. Eri mielipiteitä ilmeni vain siitä, oliko tähän tarkoitukseen käytettävä valtion tuloveroa vai liikevaihtoveroa. Edelliseen liittyvänä epäkohtana esitettiin verojen suuri kohoaminen, jälkimmäiseen taas se, että järjestelmän tuottama taloudellinen rasitus olisi silloin raskaimpana kohdistunut juuri köyhiin perheisiin, joiden asemaa ennen kaikkea oli helpotettava.

Komitean saatua mietintönsä valmiiksi ajatus yleisestä lapsilisäjärjestelmästä ei kuitenkaan vielä ollut tarpeeksi kypsynyt, jotta uudistuksen toteuttamista sen aiheuttamiin kustannuksin katsoen olisi pidetty välttämättömänä. Lisäksi Norjassakin oli Ruotsin esimerkin mukaisesti yhä enemmän alettu kiinnittää huomiota luontoissuorituslinjan mahdollisuuksiin perhekustannusten tasauksessa. Komitea katsoikin mietinnössään tarpeelliseksi puolustella raha-avustusjärjestelmän etuja samaan tapaan, kuin edellä Ruotsissa tapahtunutta kehitystä selostettaessa on mainittu. Yhtyen mm. mietinnöstä annetuista virallisista lausunnoista ilmenevään yleiseen mielipiteeseen ei maan hallituskaan sitten antanut asiasta esitystä valtiopäiville, ja toisen maailmansodan sytyttyä asia jäi lepäämään siksi, kunnes sota-ajan perheellisille tuottamat vaikeudet sen jälleen nostivat päiväjärjestykseen. Maan miehityksen viimeisessä vaiheessa — vuoden 1945 alusta lähtien — vihdoin toteutettiin osaksi komitean mietintöön perustuva lapsilisäjärjestelmä, jonka rahoittamisessa kuitenkin turvauduttiin helpoimpaan mahdolliseen keinoon, so. järjestelmä kytkettiin sairausvakuutukseen, jolloin siis sekä vakuutetut itse että työnantajat joutuivat osallistumaan rahoitukseen. Täten järjestel- 
mä ei muodostunut yleiseksi, ja se lakkasikin Norjan vapautuessa. Jo tätä ennen oli kysymystä asian vastaisesta järjestelystä pohdittu maanpaossa olevassa hallituksessa Lontoossa.

Norjan sosiaaliministeriö antoi sitten 4. 1. 1946 ehdotuksen kysymyksen uudelleen järjestämisestä väliaikaisesti, kunnes tyydyttävämpi rahoitustapa olisi keksitty. Tämänkin esityksen mukaan näet ehdotettiin lapsilisäjärjestelmä kytkettäväksi sairausvakuutukseen. Tällaisena ehdotus sai kuitenkin osakseen erittäin ankaraa kritiikkiä, kun sen mukaan suurin osa kalastajista, maanviljelijät ja muut itsenäiset elinkeinonharjoittajat sekä sellaiset palkannauttijat, joiden vuositulot olivat 9.000 kruunua suuremmat, olisivat jääneet järjestelmän ulkopuolelle. Kun osoitettiin juuri näiden yhteiskuntaryhmien olevan suuressa lapsilisän tarpeessa ${ }^{16}$, hallitus peruutti esityksensä ja antoi 2. 8. 1946 uuden esityksen yleiseksi verotuksella rahoitettavaksi koko kansan käsittäväksi lapsilisäjärjestelmäksi, jonka tuottamista kustannuksista valtio suorittaisi $7 / 8$ ja kunnat $1 / 8$. Kun lapsilisä tulisi olemaan verotettavaa tuloa, kohoaisivat kuntien verotulot kuitenkin samalla. Valtiopäiväin sosiaalikomitea yhtyi suurin piirtein tähän esitykseen 21. 9. 1946 antamassaan mietinnössä, ja tämän valtiopäivät muuttamattomana hyväksyivät. Laki lapsilisistä vahvistettiin 24. 10. 1946 ja astui voimaan takautuvasti 1. 10.1946. Ensimmäisen lapsilisän maksusuorituksen oli tapahduttava vuoden 1946 viimeisen neljänneksen päättyessä. ${ }^{17}$

\section{Perhekustannusten suuruuden arviointi.}

Perhekustannusten tasausvaatimus johti arvioimaan niiden suuruutta ei toisin sanoen kysymykseen sitä, miten paljon »lapsi maksaa». Tätä ongelmaa Ruotsissa selviteltäessä oli turvauduttava edellä mainittuun vuosien $1932-1934$ elinkustannustutkimukseen ${ }^{4}$, joka oli toimeenpantu työväestön keskuudessa. Olosuhteet muissa yhteiskuntaryhmissä olivat jossakin määrin erilaisia, mutta komitea huomautti, että mainittu väes- 
tönosa kuitenkin muodostaa tärkeän osan Ruotsin kansasta ja elintasoonsa nähden elää »keskimääräisissä» oloissa. Kulutustottumusten ja kulutuksen suuntautumisen eri tarkoituksiin e1 taas katsottu elinkustannustutkimuksen toteuttamisen jälkeisenä aikana siinä määrin muuttuneen, että tämä olisi kovin virheellisesti vaikuttanut tutkimusten tuloksiin. Perheiden tilikirjojen suoranaisella tarkastelulla ei kuitenkaan voitu saada tarpeeksi valaistusta kysymykseen perhekustannusten suuruudesta. Eihän näet voitu tietää, kuinka suuri osa esim. ravintoja asuntomenoista tuli kunkin perheenjäsenen osalle, vaikka vaatetusmenoihin nähden voitiinkin siten menetellä. Eri suuruisten perheiden menoja vertailtaessa taas oli otettava huomioon, että suuremman perheen elintaso ehkä juuri lasten lukuisuuden vuoksi oli alhaisempi kuin toisen.

Komitean toimesta laadittiin lapsen elatuskustannusten suuruuden selville saamiseksi kaksi tutkimusta. Nämä kustannukset määriteltiin tällöin siksi tulojen lisäykseksi, mikä lapsen elättämisen vuoksi olisi tarpeen, jotta perheen elintaso ei Iaskisi, tai siksi elintason laskuksi, mikä perheessä lapsen elättämisen vuoksi tapahtuu, elleivät tulot lisäänny. Ensiksi mainitussa tutkimuksessa ${ }^{18}$ elintas on mittan a käytettiin sitä osuutta perheen kaikista menoista, minkä ravin tomenot muodostavat. Tämä osuushan on - kun kerran on kysymys kaikkein välttämättömimmistä menoista - tunnetusti sitä suurempi, mitä alemmalla elintasolla perhe elää. Toistakin elintason mittaa käytettiin, nimittäin sitä osuutta kaikista menoista, minkä ns. kulttuurimenot, kirjoihin, sanoma- ym. lehtiin, terveydenhoitoon, lahjoihin, huvituksiin, matkoihin, lomanviettoon ym. kuuluvat erät käsittävät. Nämä menot ovat, ne kun ovat vähiten välttämättömiä, suhteellisesti sitä pienemmät, mitä alemmalla elintasolla perhe elää. Nyt laskettiin mainittuun elinkustannustutkimukseen nojautuen, suurenko perheen tulojen lisäyksen lapsen elättämisen vuoksi pitäisi olla, jotta sen ravinto- ja kulttuurimenot edelleenkin muodostaisivat perheen menoista saman osuuden kuin ilman tuon lapsen elättämistä. Ravintomenoprosentin nojalla laskien tultiin 
tutkimuksessa siihen tulokseen, että $7 \frac{1}{2}$ vuoden ikäinen lapsi »maksaisi» vuodessa 840 kruunua, ja kulttuurimenoprosentin nojalla päädyttiin vastaavasti 680 kruunun summaan. Laskelmat suoritettiin pitäen silmällä sellaista perhettä, jolla vuonna 1933 oli noin 4.000 kruunun vuositulot ja 1-2 lasta. Pienempien lasten tuottamat kustannukset arvioitiin - kuten onkin luonnollista - vähäisemmiksi kuin suurempien. Niinpä laskettiinkin ravintomenoprosentin nojalla, että tarvittaisiin 380 kruunun vuosittainen tulojen lisäys vastasyntyneen lapsen vuoksi, ja lapsen iän kasvaessa aina vuodella tämä summa nousee vastaavasti 61 kruunulla. Suuremmissa perheissä kustannukset ovat vähän pienemmät. - Se erotus kustannuksissa, jonka havaittiin olevan ravintomenoprosentin ja kulttuurimenoprosentin nojalla laskelmia suoritettaessa, osoittaa näiden laskutapojen erään yksipuolisuuden. Todellisuudessahan nim. lapsen elättämisen johdosta perheen ravintomenoprosentti kasvaa eikä pysy entisellään, koska lapsen menot ovat suuremmassa määrässä ravintomenoja kuin aikuisten, kulttuurimenoprosentin taas vähetessä, koska lapsen menot ovat vähäisemmässä määrässä kulttuurimenoja kuin täysikasvuisen. Ravintomenoprosentin nojalla laskien saadaan siis liian suuri ja kulttuurimenoprosentin nojalla taas liian pieni summa lopputulokseksi. Yhdessä näiden molempien laskutapojen kuitenkin katsottiin antavan väestöpolitiikalle varsin käyttökelpoisen tuloksen.

Toinen edellä mainituista tutkimuksista ${ }^{19}$ taas perustui siihen, paljonko lapsen elättämisen vuoksi kunkin menoerän pitäisi muuttua, jotta perheen elintaso ko. menoryhmän suhteen pysyisi ennallaan. Ravintomenojen kohdalla saattoi tällöin nojautua ravintoasiantuntijain eri ikäisiä henkilöjä varten esittämiin kulutusasteikkoihin. Tällöin on kuitenkin huomattava se seikka, että sama kaloriamäärä voidaan saavuttaa halvempia tai kalliimpia ravintoaineita käyttämällä. Myös vaatetuksen suhteen voidaan elinkustannustutkimuksen perusteella konstruoida kulutusasteikkoja. Asunnon suhteen saattaa menetellä esim. siten, että jos lapsettomat aviopuolisot elävät yhdessä huo- 
neessa ja keittiössä, niin katsotaan yhden tai kahden lapsen perhettä varten tarvittavan kaksi huonetta ja keittiö jne. Täten tutkija tuli siihen tulokseen, että $7 \frac{1}{1} 2$-vuotiaan lapsen osalta samanlaisessa perheessä, kuin mistä oli kysymys ensiksi mainitussa tutkimuksessa, elatuskustannukset kohoavat noin 800 $\mathrm{kruunuun}$, siis suunnilleen samaan tulokseen kuin toisessakin tutkimuksessa.

Tällaisia tuloksia siis saavutettiin kaupungeissa ja teollisuuskeskuksissa asuviin perheisiin nähden, joiden vuositulot olivat $3.000-5.000$ kruunua. Komitea huomautti, että minimikustannukset ovat pienemmät. Köyhäinhoitoavustustilasto osoittaa, että vuonna 1945 aviopuolisoille tuleva avustus halvemmilla paikkakunnilla kasvoi 300 kruunulla jokaista ensimmäistä ja toista lasta kohden sekä 240 kruunulla jokaista seuraavaa lasta kohden. Tukholmassa luvut olivat ensimmäisestä - viidennestä lapsesta vastaavasti 480, 420, 360, 300 ja 240 kruunua. Avustukset yksinäisistä lapsista olivat suuremmat. ${ }^{20}$

Norjan lapsilisäkomitean toimesta suoritettiin perhekustannusten suuruuden laskelmia siten, että arvioitiin tarpeen mukaan kuluttajayksikköperiaatteeseen nojautuen määrättyjen normien perusteella eri-ikäisten lasten menot eri menoryhmissä. Lasten tarpeet otaksuttiin tällöin tulevan tyydytetyksi verraten täydellisesti, mutta kuitenkin kansan laajoissa kerroksissa vallitsevien tapojen mukaisesti. Tulokseksi saatiin, että vuoden ikäisen lapsen aiheuttamat menot (poisluettuina synnytyksestä aiheutuneet 100 kruunua) kohoavat noin 178 kruunuun, 7-8vuotiaan 795 kruunuun (siis samaan määrään kuin Ruotsissa) ja 14-15-vuotiaan 908 kruunuun.

Verotuksen lapsivähennykset.

Kun perhekustannusten suuruuden arviointiin perustuen ryhdyttiin pohtimaan, miten suureksi lapsilisä olisi asetettava, oli otettava huomioon kaikki ne perheellisiin nähden toteutetut edut, joilla jo ennestään oli perhekustannuksia jatkuvasti tasaa- 
va vaikutus. Huomattavin tällaisista yhteiskunnan toimenpiteistä oli sekä Ruotsissa että Norjassa perheellisyysnäkökohtien soveltaminen verotukseen siten, että perheenhuoltajat valtion tuloverotuksessa saivat verotettavista tuloistaan vähentää jokaisesta huoltamastaan lapsesta tietyn, Ruotsissa paikkakuntien erilaisissa kalleusryhmissä eri suuruisen ns. lapsivähennyksen. Ruotsissa ensimmäisestä ja toisesta lapsesta myönnettiin samansuuruinen, seuraavista lapsista suurempi lapsivähennys, Norjassa taas kustakin seuraavasta huollettavasta aina suurempi vähennys. Tässä maassa verovelvolliset sitäpaitsi kuuluivat huoltovelvollisuuden mukaan eri veroluokkiin. Koska verojärjestelmä oli progressiivinen, lapsivähennyksestä koitui verovelvollisille sitä suurempi etu, mitä enemmän verotettuja tuloja oli. Myös kunnallisverotuksessa, joka molemmissa maissa on suhteellinen, lapsivähennykset olivat käytännössä.

Käsitellessään lapsilisä- ja verojärjestelmän keskinäistä niveltymistä sekä Ruotsin että Norjan komitea ensinnäkin torjui sen mahdollisuuden, että lapsilisät kokonaan voitaisiin korvata tekemällä verovähennykset tarpeeksi suuriksi. Varsinkaan valtion tuloveroa eivät lainkaan maksa suuret vähävaraiset perheet verotettavien tulojensa pienuuden vuoksi tai maksavat niitä niin vähän, että heille ei mitenkään verotuksen lapsivähennyksillä voida korvata perhekustannuksia. Niinpä perheellisten verotusta vuonna 1941 Ruotsissa tutkimaan asetetut asiantuntijat olivatkin tulleet siihen tulokseen, että edellisenä vuonna taksoitetuista perheistä, joilla oli lapsia, $2 / 5$ ei maksanut mitään tuloveroa valtiolle vastaavan luvun vähintään neljän lapsen perheissä ollessa yli $3 / 4 .^{21}$ Lapsettomat suorittivatkin yhteensä $3 / 4$ kaikista fyysillisten herkilöiden maksamista veroista. Jos taksoitetut tulot olivat 8.000 kruunua, ei lapsivähennystä neljänneltä lapselta enää täysin määrin voitu käyttää hyväksi. Kunnallisverotukseen nähden piti paikkansa, vaikkakin vähäisemmässä määrässä, sama huomautus. Lisäksi Norjan lapsilisäkomitea huomautti, että etenkin ne kunnat, joissa lapsirunsaus on suuri, elivät muutenkin taloudellisessa puutteessa, joten kunnallisverotuksen lapsivähennysten enentä- 
minen tuottaisi niille suuria vaikeuksia, mistä vielä olisi seurauksena sekin epäkohta, että verokanta muodostuisi eri seuduilla vielä enemmän erilaiseksi kuin ennen. Välillisestä verotuksesta taas huomautettiin, että ei olla selvillä siitä, suuressako määrässä se todellisuudessa rasittaa perheellisiä ainakạan välttämättömyystarvikkeiden osalta.

Mutta vaikka siis verotuksessa perheellisille annettavat edut eivät voineetkaan korvata lapsilisiä, oli ne kuitenkin otettava huomioon jälkimmäisten suuruutta määrättäessä. N o r j a s s a tämä kysymys ei herättänyt erityistä huomiota, koska siellä verotuksen lapsivähennykset jätettiin ennalle en lapsilisistä huolimatta. Tätä perusteltiin $\mathrm{mm}$. sillä, että kun lapsilisäjärjestelmä rahoitettaisiin verotuksella, ne piirit, joille lapsivähennyksistä koituu etua, toisaalta joutuisivat entistä ankaramman verotuksen alaiseksi. Toisin sensijaan kävi Ruotsissa, missä lapsilisäjärjestelmän käytäntöön ottamisen yhteydessä suoritettiin syvälle käyvä muutos valtion verotuksessa perheellisiin nähden. Kunnallisverotukseen ei Ruotsissakaan tässä yhteydessä kajottu. Kun siellä jo edellä mainittu verokomitea oli tullut siihen tulokseen, että perhekustannusten tasaaminen vaati lapsilisäjärjestelmän käytäntöön ottamista, oli se samalla esittänyt sellaisen suunnitelman, että omaksuttaisiin suoraan verosta tehtävä lapsivähennys, jonka suuruus olisi $1 \%$ taksoitetuista tuloista 10.000 kruunun tuloon asti ja tämän yli menevältä osalta $1 / 2 \% 50.000$ kruunun tuloon saakka, ja että 200 kruunun määräistä kuukautista lapsilisää supistettaisiin tällă verovähennyssummalla. Jos siis tämä olisi vähintään yhtä suuri kuin lapsilisä, ei jälkimmäistä lainkaan suoritettaisikaan.

Väestökomitea asettui tässä kysymyksessä samalle periaatteelliselle kannalle kuin verokomiteakin sikäli, että sekin katsoi asiattomaksi entisten verohelpotusten lisäksi antaa vielä lapsilisiä. Se perusteli mielipidettään sillä, että lapsivähennysten merkitys kasvaa tulojen suuretessa, mutta ei ole paikallaan, että suurempituloisten perhekustannuksia tasataan suuremmassa määrässä kuin vähempituloisten, vaikka nämä kustannukset jälkimmäisellä korkeammasta elintasolta johtuen kieltämättä ovat- 
kin suuremmat kuin edellisillä. Yhteiskunnalla ei ole aihetta korvata kuin lapsen elättämisestä koituvat minimikustannukset. Vaikka verotuksen lapsivähennysten poistaminen merkitsisikin suurempituloisille huononnusta entiseen tilanteeseen, ei se kuitenkaan olisi sitä suuruusluokkaa, että näidenkään perheiden elintaso siitä mainittavasti laskisi. Sen vuoksi komitea esitti, että omaksuttaisiin lapsilisäjärjestelmä, mutta että kokonaan poistettaisiin verotuksen lapsivähennykset. Tällöin 10.000-15.000 kruunun tuloluokkiin kuuluvissa perheissä tulisi 200 kruunun suuruinen kuukautinen lapsilisä vastaamaan ennen käytännössä olleita verohelpotuksia. Senkään seikan ei katsottu suuria merkitsevän, että lapsilisää saataisiin 16 vuotta nuoremmista lapsista, mutta verohuojennusten ikärajana sen sijaan oli 18 vuotta, koska jälkimmäinen etu annettiin vain siinä tapauksessa, että lapsella ei ole verotettua tuloa. Siinä tapauksessa taas, että lapsi ei ole työssä, vaan harjoittaa opintoja, annettaisiin lapsilisää 18 vuoden rajaan saakka.

Kun komitean ehdotus siis tuli merkitsemään verojärjestelmän radikaalista muuttamista, joka ei voinut olla käden käänteessä suoritettu ja joka $\mathrm{mm}$. edellytti muutoksia erinäisiin sosiaalipoliittisiin järjestelyihin, jotka kytkeytyivät kansalaisten verotettuihin tuloihin, komitea esitti pääehdotukselleen rinnakkaisehdotuksen, jonka mukaan verotuksen lapsivähennykset jäisivät voimaan, mutta niille, joille niistä koituu etua, maksettaisiin siinä tapauksessa, että tämä etu on suunniteltua lapsilisää pienempi, lapsilisän ja tämän välinen erotus. Haittana tässä järjestelmässä tosin olisi se, että lapsilisän suuruus olisi laskettava vanhemmilla edellisenä vuonna olleiden tulojen perusteella, jotka saattaisivat olla hyvinkin erilaiset kuin kulumassa olevan vuoden tulot.

Komitea esitti, että $\mathrm{lapsilis}$ ä t tulisivat verova pa ik$\mathrm{si}$, koska muussa tapauksessa uudistus itse asiassa merkitsisi sitä, että valtio rahasumman antaessaan lohkaisisi siitä osan pois verona. Tulojen suuretessa tämä verona otettava osa veron progressiivisuuden johdosta yhä suurenisi, joten siten vielä tehostuisi se uudistuksen epäedullisuus suurituloisille, mikä joh- 
tuisi lapsivähennysten poistamisesta. Verovapaiksi lapsilisät sitten tulivatkin. Norjassa, jossa verotuksen lapsivähennykset pysytettiin, lapsilisä sen sijaan jäi verotettavaksi tuloksi.

Sekä useimmissa Ruotsin väestökomitean ehdotuksesta annetuissa lausunnoissa että runsaassa muussakin kritiikissä ${ }^{22}$ vastustettiin lapsivähennysten poistamista ja kiinnitettiin huomiota siihen veroteorian kannalta arveluttavaan seikkaan, että vaikka komitean ehdotuksenkin mukaan vain osa perhekustannuksista siirrettäisiin vanhemmilta yhteiskunnalle, lasten toimeentulominimin verovapaus kuitenkin kokonaan poistettaisiin. Jos näet lapsen toimeentulominimiä vastaavat kustannukset arvioidaan 800 kruunuksi vuodessa, tulisi lapsilisää vastaava 200 kruunua eli siis $1 / 4$ toimeentulominimistä olemaan verovapaa, mutta $3 / 4$ verotettava. Ehdotuksen seurauksena verokuorma ei täten enää jakaantuisi verovelvollisille heidän maksukykynsä mukaan, lasten elättämisestä koituvaa veronmaksukyvyn alenemista kun tämän jälkeen ei enää verotuksessa lainkaan otettaisi huomioon. Lisäksi esitettiin, että perhekustannukset nousevat tulojen suuretessa, että naimisissa olevat naiset yhä yleisemmin jättäisivät ansiotyönsä, kun heidän veronsa nousisivat, ja että komitean ehdotus sisälsi itse asiassa huoltoperiaatteen eikä puhtaasti väestöpoliittista periaatetta, koska sen mukaan suurempituloiset joutuisivat avuistuksen tapaan luovuttamaan osan tuloistaan vähempituloisille. Arvostelevissa lausunnoissa yleensä puollettiin komitean rinnakkaisehdotuksen tapaista kombinaatiojärjestelmää tai sitä, että verovelvollinen saisi pitää verohelpotuksensa luopumalla lapsilisästä.

Vuoden 1945 verokomitean enemmistö myös asetti 19. 11. 1946 allekirjoittamansa mietinnön perustaksi väestökomitean ehdotuksen esittäen samanlaisia perusteluja kuin jälkimmäinenkin. $^{23}$ Komitea ei pitänyt kestävänä sitä periaatetta, että toimeentulominimiä vastaavan tulon pitää olla verovapaa. Valtion varoista kustakin lapsesta maksettavan edun tulee kaikille lapsille olla samansuuruinen. Uudistus merkitsisi kuitenkin etua verovelvollisten suurelle enemmistölle. Yksi tämän komitean jäsen ehdotti vastalauseessaan, että lapsilisää alettaisiin suorit- 
taa vasta toisesta lapsesta ja että täten koituvan säästön turvin voitaisiin säilyttää verotuksen lapsivähennykset. Tämän suuruus voisi olla ensimmäisestä ja toisesta lapsesta 800 ja kustakin seuraavasta lapsesta 1.200 kruunua.

Hallitus asettui tässä kysymyksessä komitean kannalle tähdentäen sitä, että komitean ehdotus toteuttaisi väestöpoliittisen periaatteen, kun sen mukaan kaikissa tuloluokissa perheellisille tulisi suuremmat edut kuin perheettömille.

Kysymys lapsilisäjärjestelmän niveltymisestä verotukseen laajeni täten puhtaasti väestöpoliittisesta jakaantumis- ja yleispolittiseksi kysymykseksi, hallituksen ehdotus kun tuli olemaan epäedullinen suurempituloisille sekä verotuksen lapsivähennysten poistamisen johdosta että sen vuoksı, että verorasitusta muutenkin heille entistä enemmän siirrettiin. 'Tämä kysymys olikin ainoa melkoista erimielisyyttä herättävä kohta muuten niin suurella yksimielisyydellä vastaanotetussa uudistussuunnitelmassa. Kysymyksestä käytiin sanomalehdistössä ja valtiopäivillä kovia väittelyitä, ja jälkimmäisille esitettiinkin oikeiston taholta ehdotuksia, joista eräässä ehdotettiin hallituksen esitys hylättäväksi ja pyydettiin uutta monipuolisempaan selvitykseen perustuvaa esitystä ${ }^{24}$ ja toisissa taas niin muutettavaksi, että verotuksen lapsivähennykset säilytettäisiin ja että lapsilisän suuruus määräytyisi perheen tulojen mukaan. ${ }^{25}$ Itsestään tarjoutuvana perusteluna näiden ehdotusten tekijöillä oli se tosiasia, että hallituksen ehdotus oli sikäli ristiriidassa perhekustannusten tasaamisen periaatteen kanssa, että uudistus olisi tietyissä tuloluokissa entiseen tilanteeseen verrattuna perheille jatkuvasti sitä epäedullisempi, mitä enemmän niissä on lapsia. Myös tähdennettiin sitä, että ei ole riittävästi selvitetty väestöpoliittisten toimenpiteiden kokonaisuuden kannalta tärkeää kysymystä, suurtako etua kansalaisille merkitsevät jo käytännössä olevat perhekustannusten tasaamismuodot, ja että huolenpito valtion finansseista ei salli niin kallista uudistusta aikana, jolloin yhä yltyvä inflaatiovaara on uhkaamassa. Nämâ muutosehdotukset kuitenkin hylättiin ja hallituksen esitys hyväksyttiin. 
Millainen merkitys tällä kysymyksellä perheellisille oli, käy ilmi seuraavasta yhdistelmästä, jossa on esitetty, suurtako vuotuista voittoa tai tappiota 260 kruunun määräisen lapsilisän käytäntöön ottaminen ja samanaikaisesti tapahtuva verotuksen lapsivähennysten kumoaminen verovelvollisille merkitsi. ${ }^{26}$ Taksoitetuksi tuloksi on tällöin ilmoitettu se summa, mikä saadaan, kun tuloista tehdään $\mathrm{ns}$. yleiset vähennykset ja vähennetään edellisenä vuonna maksettu kunnallisvero.

Taksoitettu Voitto $(+)$ tai menetys $(-)$, kruunua, kun lapsia on tulo, kruunua 1

Kalleusryhmä I

(maaseutu)

$\begin{array}{rrrrr}1.000 & +265 & +525 & +785 & +1.045 \\ 2.000 & +282 & +525 & +785 & +1.045 \\ 3.000 & +295 & +526 & +741 & +995 \\ 5.000 & +310 & +482 & +649 & +864 \\ 8.000 & +315 & +470 & +570 & +677 \\ 10.000 & +308 & +446 & +525 & +625 \\ 12.000 & +313 & +427 & +484 & +553 \\ 13.000 & +321 & +421 & +467 & +515 \\ 15.000 & +309 & +392 & +403 & +419 \\ 17.000 & +254 & +333 & +317 & +308 \\ 18.000 & +230 & +275 & +260 & +244 \\ 20.000 & +185 & +219 & +135 & +69 \\ 25.000 & -78 & -44 & -128 & -212 \\ 50.000 & -889 & -952 & -1.183 & -1.413 \\ 110.000 & -1.400 & -1.563 & -1.946 & -2.329 \\ 210.000 & -337 & -551 & -1.013 & -1.475\end{array}$

Kalleusryhmä V (Tukholma)

$\begin{array}{rrrrr}1.000 & +265 & +525 & +785 & +1.045 \\ 2.000 & +265 & +525 & +785 & +1.045 \\ 3.000 & +315 & +535 & +785 & +1.045 \\ 5.000 & +278 & +453 & +653 & +853 \\ 8.000 & +285 & +404 & +462 & +624 \\ 10.000 & +270 & +369 & +414 & +459 \\ 12.000 & +261 & +340 & +350 & +384 \\ 13.000 & +274 & +335 & +327 & +337 \\ 15.000 & +265 & +304 & +240 & +213\end{array}$




$\begin{array}{rrrrr}17.000 & +225 & +241 & +144 & +69 \\ 18.000 & +167 & +183 & +73 & -13 \\ 20.000 & +129 & +84 & -82 & -192 \\ 25.000 & -114 & -158 & -360 & -562 \\ 50.000 & -976 & -1.150 & -1.550 & -1.949 \\ 110.000 & -1.541 & -1.851 & -2.454 & -3.058 \\ 210.000 & -482 & -861 & -1.571 & -2.280\end{array}$

Lapsilisälain hyväksyminen merkitsi siis niille perheille, joiden vuositulot olivat Tukholmassa $20.000-25.000$ ja halvimmilla paikkakunnilla $17.000-20.000$ kruunua suuremmat, tappiota. Sosiaaliministeri Möllerin ilmoituksen mukaan sellaisia perheitä, joille uudistuksesta olisi taloudellista hyötyä, tulisi olemaan noin $95 \%$ kaikista perheistä. ${ }^{27}$ Ruotsissakin tapahtunut $r$ ah an arvon aleneminen on kuitenkin lain voimassa oloaikana tullut muuttamaan näitä edellytyksiä. Että voitto tietyissä tuloluokissa muodostui kunkin lapsen osalta suuremmaksi kuin lapsilisän koko määrä, 260 kruunua, ja että luvut edellä olevan asetelman sarekkeissa eivät jatkuvasti muutu samaan suuntaan, johtuu siitä, että myös verotaulukot uusittiin.

\section{Lapsilisän määrä.}

Perhekustannuksia koskevat laskelmat, joissa siis sekä Norjan että Ruotsin osalta oli päädytty siihen tulokseen, että 7-8vuotiaan lapsen elättäminen tulee maksamaan keskimäärin noin 800 kruunua vuodessa, tarjosivat luonnollisen lähtökohdan lapsilisän määrää koskevalle pohdinnalle. Yksimielisiä kummassakin maassa oltiin siitä, että perhekustannust en täydellinen tasaminen ei voinut tulla kysymykseen. Uudistuksen toteuttamiseksi tarvittavien varojen runsaudesta puhumattakaan tätä näkökantaa pidettiin oikeutettuna siksi, että perhekustannukset suuresti vaihtelevat tulojen mukaan ja ettâ valtion voi katsoa olevan syytä pyrkiä vain minimikustannusten korvaamiseen eli toisin sanoen 
niiden kustannusten, joita lapsen kohtuulliset vaatimukset täyttävä elämä välttämättömästi edellyttää. Norjan komitea tähdensi myös sitä, ettei pitäisi ottaa vanhemmilta itseltään pois päävastuuta lasten elättämisestä ja kasvattamisesta, jotta heidän työhalunsa ja yrittämistahtonsa ei heikkenisi. Väestöpoliittisistakaan syistä komitea ei pitänyt perhekustannusten täydellistä tasaamista välttämättömänä, sillä se katsoi halun saada lapsia olevan niin suuren, että se aina vastaa tietynsuuruista osaa perhekustannuksista. Kun komitea arveli kestävän vielä pitkän ajan, ennenkuin sen suunnittelema uudistus olisi käytännössä toteutettu, se ei omaksunut mitään määrättyä kantaa lapsilisän määrään nähden, vaan esitti laskelmansa kahta eri vaihtoehtoa, 120 ja 100 kruunun suuruista vuosittaista lisää silmällä pitäen. Lisän suuruudeksi Norjan sosiaaliministeriö esitti sekä ensimmäisessä että toisessa ehdotuksessaan 200 kruunua, mutta lopulliseksi päätökseksi tuli 180 kruunua, kun valtiopäiväin sosiaalikomitea ei katsonut voivansa ehdottaa kokonaiskustannusten lisäämistä, mutta kun se toisaalta kuitenkin piti tarpeellisena järjestelmän laajentamista koskemaan myös ensimmäisiä lapsia sellaisissa tapauksissa, että lapsi on avioton tai että hänen vanhempansa ovat eronneet tai että toinen heistä on kuollut.

Ruotsissa lapsilisän suuruutta määrättäessä oli otettava huomioon muut jo ennen toteutetut perhekustannusten tasaamistoimenpiteet. Näihin väestökomitea liitti myös valmisteltuja, mutta vielä toteuttamatta olevia uudistuksia. Tärkeimmät näistä olivat asuntososiaalisen komitean esittämät perheasuntoavustukset (familjebostadsbidrag), jollaiseksi vuoden 1947 valtiopäivillä sitten hyväksyttiin 130 - 175 kruunua vuodessa 16 vuotta nuoremmalta lapselta ja jollaista oli oikeus saada vähävaraisen perheen, jolla on vähintään kaksi mainitunikäistä lasta ja sekä laadun että koon puolesta määrätyt vaatimukset täyttävä asunto uudessa kiinteistössä. Tämän lisäksi annetaan taloudelle vielä 125-175 kruunun polttoaineavustus (bränslebidrag).28 Käytäntöön otettujen yleisten ilmaisten kouluateria in 
tuottaman edun taas arvioitiin nousevan 100 kruunuun vuodessa. Täten komitea tuli sihen tulokseen, että 200 kruunun suuruinen vuotuinen lapsilisä olisi paikallaan. On kuitenkin huomattava, että maksuttomat kouluateriat eivät vielä ole käytännössä läheskään kaikissa Ruotsin kouluissa ja että asuntoa koskevien määräysten ja tulorajan rajoittamasta perheasuntoavustusten saannista tulevat vain harvat perheet osallisiksi.

Komitean ehdotuksesta annetuissa lausunnoissa kiinnitettiin huomiota siihen epävarmuuteen, mikä liittyi suoritettuihin perhekustannusten laskelmiin, nämä kun nojautuivat vain tiettyyn työväestön ryhmään, ja pidettiin lapsilisää kaupunkioloissa liian pienenä. Viitattiin siihen, että ehdotettu summa peittäisi todellisista lapsenelatuskustannuksista vain $1 / 5$ sekä asuntososiaalisen komitean ehdottaman perheasuntoavustuksen ja kouluateriain kanssa yhdessä vain puolet. Muutamat lausunnonantajat pitivät parempana, että perheasuntoavustukset samoinkuin eräät muutkin komitean esittämät perheavustukset sisällytettäisiin yleisiin lapsilisiin.

Antamassaan esityksessä hallitus olikin korottanut lapsilisäksi aiotun 200 kruunun summan $260 \mathrm{kruunuksi}$ perustellen tätä muutosta sillä, että niinkin suuri lapsilisä voitaisiin rahoittaa, kun väestökomitea oli arvioinut verotuksen lapsivähennysten poistamisesta valtiolle tulevan edun liian vähäiseksi, ja että lapsilisäsumman nostaminen vähentäisi niiden perheiden lukua, joille verotuksen lapsivähennyksen poistamisen vuoksi uudistus merkitsisi huononnusta entisiin etuisuuksiin verrattuna. Lisäksi oli komiteanmietinnön valmistumisen jälkeen elintarvikkeiden hinnanalennusjärjestelmä kumottu, ja hintataso oli yleensäkin noussut. - Hallituksen esittämäksi lapsilisän määrä sitten valtiopäiväkäsittelyssäkin jäi.

Sellainen mahdollisuus oli kuitenkin olemassa, että lapsilisä ei jokaiselta lapselta olisi samansuuruinen, vaan määräytyisi lapsen järjesty sluvun mukaan. Molemmissa maissa toimineet komiteat huomauttivatkin, että perhekustannukset lasta kohden ovat yleensä sitä pienemmät, mitä enemmän lapsia perheessä on. Tämä johtuu siitä, että useat lapset voivat käyt- 
tää yhteisiä hyödykkeitä, niin että jokaiselle lapselle ei ole tarpeen hankkia siinä määrin tarvikkeita, kuin olisi välttämätöntä perheen ainoalle lapselle. Esim. ravintoaineiden määrä jää ruokaa valmistettaessa henkeä kohden suuressa perheessä vähäisemmäksi kuin pienessä, ja vaatteet ja jalkineet saattavat osittain siirtyä vanhemmilta lapsilta nuoremmille. Samaten asuntomenot lasta kohden pienenevät perheen kasvaessa. Norjan lapsilisäkomitean enemmistö ehdottikin, että lisä toisesta lapsesta olisi $75 \%$ ja kolmannesta ja sitä seuraavista lapsista $50 \%$ siitä, mitä se olisi ensimmäisestä lapsesta, vähemmistön taas ollessa sitä mieltä, että lisän pitäisi olla samansuuruinen kaikista lapsista. Perhekustannuksethan voidaan ehdotetuilla lapsilisillä korvata vain osaksi, vaikka otetaankin huomioon muutkin perheen tukemistoimenpiteet, ja tästä seuraa, että lisistä huolimatta perheen suurenemisesta on seurauksena sen elintason aleneminen. Vaikka tämä uudistus toteutettaisiinkin, perhekustannukset siis jäisivät sitä suuremmiksi, mitä enemmän lapsia on. Täten olisi tarpeen korvata useamman lapsen elättäjille suurempi osa perhekustannuksista kuin vain harvojen lasten huoltajille. Kaikista kapsista maksettavan samansuuruisen lapsilisän kannalle Norjassa sitten myöhemminkin asetuttiin, samaten kuin Ruotsissakin.

Ruotsin valtiopäivillä oikeiston edustajien taholta kuitenkin ehdotettiin - mikäli vastoin sen kantaa verotuksen lapsivähennykset poistettaisiin - n o u se va a a s teik k o a lapsiluvun kasvaessa, toisin sanoen sellaista järjestelmää, että myöhemmistä lapsista annettaisiin suurempi lapsilisä kuin aikaisemmista. ${ }^{29}$ Täten olisi jossain määrin, lievittynyt se hallituksen ehdotuksen epäkohta, että uudistus muodostuisi suurituloisille sitä epäedullisemmaksi, mitä enemmän lapsia heillä olisi. Tälle ehdotukselle saatettịin käyttää hyväksi väestöpoliittisia perusteita. Tärkein perhesosiaalinen tehtävä olisi nyt - niin muutosehdotuksen tekijät huomauttivat - auttaa nimenomaan suuria perheitä, joiden vanhemmat ovat ottaneet vastatakseen ja huolehtiakseen suuren lapsijoukon kasvatuksesta. Olisi estettävä tällaisten perheiden elintason laskeminen matalammaksi kuin pienten per- 
heiden. Aikana, jolloin yksi- ja kaksilapsijärjestelmä on tullut yhä tavallisemmaksi laajoissa piireissä, on mahdotonta olla näkemättä, että tällä hedelmällisyyden laskulla on taloudelliset syyt. Lapsilisäjärjestelmä ei ole tarkoitettu vain sosiaaliseksi tasoitukseksi huoltovelvollisten ja ei-huoltovelvollisten kesken, vaan sen on myös tulevaisuuden työvoiman tarpeen tyydyttämiseksi omaksuttava väestöpoliittiset päämäärät. Huomautettiin, että tällainen periaate ei ole uusí, voimassa olevassa verojärjestelmässäkin kun kahdesta ensimmäisestä lapsesta saa tehdä pienemmän vähennyksen kuin seuraavista lapsista. Ensimmäisestä lapsesta lapsilisä voisi olla esim. 150, toisesta 300 sekä kolmannesta ja kustakin sitä seuraavasta lapsesta 450 kruunua. Aviottomista lapsista lisä kuitenkin voisi olla samansuuruinen. - Nämä muutosehdotukset kuitenkin hylättiin ja samansuuruinen lapsilisä kaikista lapsista hyväksyttiin.

Myöskin sellaisia ajatuksia esitettiin, että lapsilisän pitäisi määräytyä perheen tulo jen mukaan, kuten tulorajaa koskevaa kysymystä seuraavassa (ss. 62-64) selostettaessa mainitaan.

Perhekustannukset vaihtelevat myös paikkakuntien kalleuden mukaan samaan tapaan kuin elinkustannukset yleensä. Ruotsin väestökomitean käytettävänä olleet laskelmat eivät kuitenkaan riittävästi selvittäneet tätä kysymystä. Komitea omaksuikin tässä suhteessa saman kannan kuin aikaisemmin sosiaalihuoltokomitea, nim. että elinkustannusten eroavuudet eri paikkakuntien kesken eivät ole tarpeeksi suuret, jotta niillä voitaisiin perustella kalleusryhmitystä muilla aloilla kuin kysymyksen ollessa perheasuntoavustuksista. Sen tähden lapsilisän ei tarvitsisi määräytyä paikkakunnan kalleuden mukaan. Kun lasten ikä, järjestysluku ja asuinpaikka eivät täten vaikuttaisi lapsilisän määrään, saavutettaisiin hallinnollinen yhtenäisyys lapsilisän suorittamisessa.

Kaupunkilaispiirejä edustavat lausunnonantajat pitivät kuitenkin paikkakuntien kalleusryhmitystä perusteltuna, koska perhekustannukset kaupungeissa nousevat suuremmiksi kuin maaseudulla ja koska perheasuntoavustuksissakaan ei vielä ollut otettu huomioon kalleusryhmitystä. Lisäksi verotuksen lapsi- 
vähennysten poistamisesta koituisi kaupunkilaisille suurempi menetys kuin maalaisille. Hallituksen esityksessä asetuttiin kuitenkin sille komitean jo esittämälle kannalle, että eroavuudet eri paikkakuntien elinkustannusten kalleudessa johtuvat ensi sijassa juuri erilaisista asumiskustannuksista, ja valtiopäivät olivat samaa mieltä. Samalla tavalla tämä kysymys ratkaistiin myös Norjassa.

Kysymys lapsilisän saannin rajoituksista.

Perheen suuruus. Jotta perhekustannusten tasaus voitaisiin mahdollisimman täydellisesti toteuttaa, oli sekä Ruotsin että Norjan komitean mielestä jokaisesta lapsesta suoritettava vanhemmille lapsilisää. Komiteat totesivat kuitenkin samalla, että tällaisen uudistuksen rahoitusvaikeudet olivat monessa maassa, esim. Suomessa, pakottaneet tinkimään tästä periaatteesta ja jollakin tavoin rajoittamaan lapsilisää saavien lukua. Mikäli tällaisia rajoituksia oli otettava käytäntöön, molemmat komiteat pitivät lasten lukumäärää huomattavasti objektiivisempana ja luonnollisempana perusteena kuin esim. tulorajaa, koska elintasojen keskinäinen eroavuus on keskimääräisesti katsoen huomattavasti suurempi kahden sellaisen perhęen kesken, joista toisessa on yksi lapsi enemmän kuin toisessa, kuin sellaisten perheiden kesken, joiden tulot ovat jonkun enemmän tai vähemmän mielivaltaisesti valitun tulorajan eri puolilla sitä lähellä.

Ruotsin väestökomitea piti mahdollisena verotuksella rahoittaa täysin yleisenkin lapsilisäjärjestelmän, ja sen vuoksi se ehdotti, että lapsilisää maksettaisiin kaikista lapsista. Mikäli asian myöhemmässä käsittelyvaiheessa päädyttäisiin siihen, että valtiotalouden tila ei sallisi näin perusteellista uudistusta, komitea esitti väliaikaisena ratkaisuna, että lapsilisää suoritettaisiin vasta toisesta lapsesta lähtien tai ensimmäisestä lapsesta vain vähävaraisille ja kaikille lapsille toisesta alkaen. Myös useissa komitean ehdotuksesta annetuissa lausunnoissa puolus- 
tettiin taloudellisista syistä sellaista kantaa, että lapsilisää olisi maksettava vasta toisesta lapsesta lähtien. Myös esitettiin se ajatus, että täten lapsilisä voitaisiin tehdä suunniteltua suuremmaksi, joten perhekustannusten tasauskin tällöin tulisi tehokkaammaksi. Huomautettiin myös siitä, että useat muut perhekustannusten tasausmuodot, esim. ilmaiset kouluateriat, tulevat jo ensimmäisenkin lapsen hyväksi. Hallitus ja valtiopäivät asettuivat kuitenkin komitean kannalle, ja lapsilisäjärjestelmä tulı lasten lukumääräänkin nähden yleiseksi.

Kun Norjassa todettiin kustannusten lapsilisäjärjestelmästä supistuvan, jos lisää alettaisiin suorittaa vasta toisesta lapsesta, noin puoleen siitä kuin siinä tapauksessa, että järjestelmä koskisi kaikkia lapsia, hallituksen vuonna 1946 antamat molemmat esitykset rakentuivat ensiksi mainitulle vaihtoehdolle. Samalle kannalle valtiopäivätkin asettuivat, mutta tekivät kuitenkin hallituksen esitykseen sen lisäyksen, että lisää suoritettaisiin jo enșimmäisestä lapsesta siinä tapauksessa, että ainakin toinen lapsen vanhemmista on kuollut, että he ovat eronneet tai että lapsi on avioton, mikäli eivät molemmat vanhemmat lasta elätä, koska tällaiset lapset ovat erityisen suuren avun tarpeessa. Tällöin täytyi lisän suuruus kuitenkin laskea hallituksen ehdottamasta 200 kruunusta 180 kruunuun.

Pohdittaessa kysymystä perheen suuruudesta lapsilisän saannin ehtona jouduttiin koskettelemaan monia muitakin tässä kysymyksessä huomioon otettavia seikkoja. Komiteat toteșivat, että monessa maassa on väestöpoliittisten näkökohtien vaikutuksesta päädytty siihen, että lapsilisää suoritetaan vain suurten perheiden lapsille, koska väestökriisi on ilmaantunut juuri sillä tavoin, että järjestysluvultaan myöhemmät lapset ovat tulleet harvinaisemmiksi, joten ei ole ollut erityistä syytä kiihoittaa ensimmäisen ja toisen lapsen hankkimiseen. Mm. Suomessa perhelisää suoritettiin vuoteen 1946 saakka vasta viidennestä lapsesta alkaen. Toiselta puolen voitiin kuitenkin huomauttaa, että vapaaehtoisesti lapsettomienkin perheiden luku on melkoinen. Perhe ei voi tulla suureksi, ellei se aloita yhdellä ja kahdella lapsella. 
Kun komiteat sitten kiinnittivät huomiota oikeudenmukaisuusnäkökohtiin, ne totesivat, että jo yhdenkin lapsen huoltajien perhekustannuksia on tasattava, heidän elintasonsa kun verrattaessa sitä yksinäisen henkilön elintasoon muuten liian suuressa määrässá alenisi. Jos lapsilisää annettaisiin vasta myöhemmistä lapsista, apua vaille jäisivät juuri nuoret perheet, jotka ennen kaikkea sitä tarvitsevat. Ensimmäisen lapsen synnyttyä äiti myös usein jää kotiin ansiotyöstään, ja siten perheen toimeentulomahdollisuudet heikkenevät. Muutenkin kustannukset ensimmäisestä lapsesta ovat suuremmat kuin seuraavista. Köyhissä oloissa elävä pieni perhe voi kipeämmin tarvita lapsilisiä kuin hyvin toimeentuleva suuri perhe. Toiselta puolelta voidaan huomauttaa, että perheiden elintaso yleensä on sitä alhaisempi, mitä suurempia ne ovat, ja että siten lapsilisä juuri suurille perheille on kaikkein kipeimmän tarpeen vaatima.

Tässä yhteydessä jouduttiin kajoamaan myös palkkateoreettiseen kysymykseen, onko kohtuullisen palkan käsitteeseen katsottava kuuluvan sen tunnusmerkin, että palkansaaja palkallaan voi elättää paitsi itsensä, vaimonsa ja esim. yhden lapsen. Jos näin yleisesti myönnettäisiin olevan, niin silloin jo ensimmäisestä lapsesta annettaviin lapsilisiin helposti voisi liittyä pyrkimys pitää palkkataso liian alhaisena.

I kär a ja. Kuten Ruotsin väestökomitean toimesta suoritetuista lapsen elatuskustannuksia koskevista laskelmistakin oli käynyt selville, nämä kustannukset lapsen iän mukana kasvavat. Vastakkaiseen suuntaan taas vaikuttaa se, että lapsen hoitajalleen aiheuttama työmäärä vähenee hänen varttuessaan. Kun lisäksi eräät muut perhekustannusten tasausmuodot, kuten $\mathrm{mm}$. ilmaiset kouluateriat, koituvat lasten hyväksi vasta heidän myöhemmällä iällään, komitea asettui sille kannalle, että lapsilisän olisi oltava samansuuruinen eri ikäisille alaikäisille lapsille. Tässä suhteessa ei suurempia erimielisyyksiä asian myöhemmissäkään käsittelyvaiheissa Ruotsissa eikä Norjassa ilmaantunut. 
Mitä tulee siihen ikärajaan, jota nuoremmille lapsilisää oli suoritettava, Ruotsinn väestökomitea totesi sen seikan, että murrosiässä lapsen elatuskustannukset ovat erityisen suuret, motivoivan korkeaa ikärajaa. Toisaalta taas oli otettava huomioon, että suurin osa nuorista menee 14-15-vuotiaina kansakoulusta päästyään ansiotyöhön. Täten komitea päätyi ehdotukseen, että lapsilisää annettaisiin vielä sinä vuonna, jona lapsi täyttää 16 vuotta. Oppivelvollisuusajan piteneminen lähitulevaisuudessa oli näet odotettavissa. Erityisiä määräyksiä komitea ja hallitus kuitenkin pitivät tarpeellisena sellaisissa tapauksissa, että nuoret jatkavat opintojaan tai että he ovat pysyvästi työkyvyttömiä. Viitaten siihen, että tuloverotuksen lapsivähennyksetkin saadaan tehdä lapsista, joilla ei ole verotettavaa tuloa, aina 18 vuoden ikään saakka, komitea ehdotti, että lapsilisää erityisestä anomuksesta suoritettaisiin vielä 16 -vuotiaaksikin tulleesta lapsesta enintään kahtena vuotena, mikäli lapsella ei ole tilaisuutta omalla työllään ratkaisevassa määrässä kustantaa elatustaan.

Näitä perusteluja ei valtiopäiväin valiokunnassa ja täysiistunnoissa kuitenkaan pidetty tarpeeksi painavina, vaan viitattiin siihen, että säännösten välttämätön epämääräisyys tässä suhteessa tulisi asettamaan lastenhuoltolautakunnat hyvin vaikean tehtävän eteen, kun heidän olisi ratkaistava, suoritetaanko jostakin lapsesta lisää vai ei. Opiskelukustannusten korvausta olisi annettava stipendien ja sairaskustannusten jossakin muussa muodossa. Hyväksytyn lapsilisälain mukaan oikeus lisän saantiin siis joka tapauksessa oli lakkaava, kun lapsi täyttää 16 vuotta. Samanlainen päätös Norjassakin tehtiin. Sikäläinen komitea oli ikärajaksi ehdottanut 15 vuotta.

Tuloraja. Mikäli lapsilisän saantia oli valtiotaloudellisista tai muista syistä rajoitettava, saattoi edellä käsiteltyjen rajoitusperusteiden lisäksi tulla kysymykseen lisän antaminen vain niille, joille se taloudellisesti oli kaikkein välttämättömintä. Tällaistakaan rajoitusta eivät asiaa käsitelleet komiteat kuitenkaan katsoneet olevan syytä ottaa käytäntöön, koska kumpikin niistä lähti kokonaan perhekustannusten yleisen tasauksen 
periaatteesta, ja tämä taas edellyttää, ettei rajoituta vain joihinkin määrättyihin tuloluokkiin. Kustannuksiakaan ajatellen ei ollut syytä tällaiseen rajoitukseen. Jotta järjestelmällä olisi huomattavaa. merkitystä, olisi lapsilisän saannin ehtona oleva tulojen yläraja joka tapauksessa asetettava huomattavan korkealle, jotta kansan laajat piirit pääsisivät uudistuksesta osallisiksi, ja tällöin kustannusten säästö taas olisi vain vähäinen. Tämänkin säästön tekisi merkityksettömäksi hallintomenojen nousu, mikä olisi seurauksena tuollaisen rajoituksen aiheuttamasta järjestelmän monimutkaistumisesta. Lisäksi tämäntapainen tuloraja antaisi lapsilisille käyhäinavustuksen luonteen, joten sitä ei pidettäisi - niinkuin tarkoitus oli korvauksena yhteiskunnalle ensiarvoisen tärkeästä työstä, jota lasten kasvattajat suorittavat. Sitäpaitsi sen ratkaiseminen, mihin kohtaan tuloraja olisi asetettava, muodostuisi pakostakin mielivaltaiseksi.

Ruotsin väestökomitean ehdotuksesta annetuissa kaikissa lausunnoissa ei samaten kuin Norjankaan komitean ja sosiaaliministeriön esitysten aiheuttamassa kritiikissä kuitenkaan oltu yhtä vakuuttuneita siitä, että teoreettisista syistä olisi johdonmukaisesti toteutettava »sama kaikille» periaate, ja huomautettiin, että tällainen menettely sulkisi pois mahdollisimman tehokkaan avun keskittymisen sinne, missä sitä kipeimmin tarvittaisiin. Joissakin lausunnoissa taas ehdotettiin, että lapsilisää olisi annettava alemmissa tuloluokissa yleisesti, mutta ylemmissä vain välttämättömiksi osoittautuvissa tapauksissa.

Ruotsin hallituksen esityksessä kuitenkin huomautettiin, että suurituloiset joutuvat veroillaan maksamaan pienempituloisten lapsilisät, ja sen vuoksi ei ole oikein heitä sulkea pois lisän saannista. Sellainen järjestelmä taas, että lapsilisä pienenisi tulojen suuretessa, vaatisi hankalaa ja monimutkaista organisaatiota. Ne syyt, joilla voitiin puoltaa lapsilisän maksamista vain pienempituloisille, vielä vähenisivät, kun verotuksen lapsivähennykset, jotka ennen kaikkea olivat tulleet juuri suurempituloisten hyväksi, poistettaisiin. 
Ruotsin valtiopäivillä asiaa käsiteltäessä koetettiin oikeiston taholta taistelussa lapsivähennysten poistamista vastaan vielä puoltaa sellaista järjestelmää, että 260 kruunun suuruinen lapsilisä annettaisiin vain niille, joiden taksoitetut vuositulot olisivat 5.000 kruunua pienemmät, mutta että lisä tulojen ollessa 5.000 -7.999 kruunua olisi 200 kruunua, 8.000-12.999 kruunun tuloluokissa 150 ja $13.000-19.999$ kruunun tuloluokissa 100 kruunua. Ne, joilla olisi vähintään 20.000 kruunun vuositulot, eivät lainkaan saisi lapsilisää..5 Perusteluna esitettiin tăllöin, että perhekustannusten tasaaminen jo on toteutettu ylemmissä tuloluokissa verohelpotusten muodossa, mutta ei vielä alemmissa. Samansuuruiseksi kaikilta lapsilta lisä kuitenkin sekä Ruotsissa että Norjassa jäi.

Lapsilisän suorittaminen.

Sekä Ruotsissa että Norjassa lapsilisän saantiin oikeutetut velvoitettiin tekemään tästä oikeudestaan samoinkuin tähän vaikuttavien olosuhteiden muutoksistakin ilmoitus paikalliselle hallintoelimelle. Kun Ruotsissa lapsilisää ehdotettiin suoritettavaksi myös 16-18-vuotiaille, mikäli he eivät omalla työllään ratkaisevasti voi kustantaa omaa elatustaan, olisi tällaisissa tapauksissa kuitenkin ollut tarpeen erityinen anomus, jossa annetut tiedot tarkistaisi paikallinen hallintoelin ja jonka ratkaisisi lääninhallitus. Tätä kysymystä koskevaa pohdintaa ${ }^{30}$ ei kuitenkaan ollut tarpeen jatkaa, koska valtiopäiväin päätöksen mukaan lapsilisiä ei tultukaan suorittamaan 16 vuotta vanhemmille.

Norjassa paikalliset vanhuusvakuutuslautakunnat, alderstrygdnemnder, saivat tehtäväkseen huolehtia postiosoitusten kirjoittamisesta ja lähettämisestä lapsilisän saantiin oikeutetuille. Lapsilisäasiain hoidon keskuselimeksi taas tuli sosiaaliministeriö. Myös Ruotsissa väestökomitea ja hallitus asettuivat sille kannalle, että lapsilisäasiain hoidosta olisi huolehdittava kuntien toimesta. Tätä tarkoitusta varten komitea esitti perustet- 
tavaksi kuhunkin kuntaan perhelautakunnan, jonka hoitoon siirtyisivät myös lastenhuoltolautakunnalle kuuluneet tehtävät. Perhelautakunnan päätöksistä voitaisiin valittaa lääninhallitukseen ja tästä edelleen sosiaalihallitukseen, joka toimisi lapsilisäasiain keskuselimenä. Komitean mietinnöstä annetuissa lausunnoissa puollettiin kuitenkin yleisemmin keskitettyä järjestelmää, jonka vallitessa yksi viranomainen huolehtisi koko maassa lapsilisien maksattamisesta. Hallitus taas katsoi esityksessään, että kunnalliset lastenhuoltolautakunnat voisivat hoitaa lapsilisiä koskevia asioita, koska se oli sitä mieltä, että keskitetyn järjestelmän omaksuminen aiheuttaisi uudistuksen lykkäämisen tuonnemmaksi, se kun edellyttäisi niin suuritöisiä valmisteluja. Samalle kannalle valiokunta ja valtiopäivätkin asettuivat, vaikka näillä puollettiin keskitettyäkin järjestelmää ja huomautettiin, että sen vallitessa tarvittava lisätyömäärä supistuisi paljon pienemmäksi, kuin olisi laita siinä tapauksessa, että postiosoitukset kirjoitettaisiin lastenhuoltolautakunnissa, ja että täten saavutettaisiin suurempi yhdenmukaisuus järjestelmän toteuttamisessa. ${ }^{31}$

Norjan lapsilisäkomitea oli esittänyt, että lisän olisi oikeutettu nostamaan se, jonka hoidossa lapsi on. Mikäli lapsi olisi molempien vanhempien huollossa, olisi jommallakummalla heistä tuo oikeus. Asiaa myöhemmin käsiteltäessä omaksuttiin se periaate, että lapsilisä tällaisessa tapauksessa on maksettava lapsen ä i dille, keska tällöin saadaan parhaat takeet siitä, että lisä todellakin tulee lapsen hyväksi., Tälle kannalle myös Ruotsin komitea asettui. Lapsilisän maksamista koskevassa mietinnössään asiantuntijat samoinkuin muutamat lausumnonantajatkin asettuivat kuitenkin puoltamaan sitä, että isä olisi oikeutettu nostamaan lapsilisän, koska hän Ruotsin kansan laajoissa piireissä vallitsevan tavan mukaan vastaa perheen taloudesta. Hallitus katsoi kuitenkin niiden perusteiden olevan painavampia, joilla oli puollettu äidin oikeutta tässä suhteessa. Tälle kannalle asian myöhemmissäkin käsittelyvaiheissa asetuttiin. Siinä tapauksessa, että lapsi on valtion laitoksessa, jossa hoito on maksuton, lapsilisää ei suo- 
riteta. Lastenhuoltolautakunnalla on myös oikeus määrätä, että lapsilisä on suoritettava muulle kuin sille, jolle lisä yleisen säännön mukaan olisi maksettava, mikäli tätä henkilöä ei voida pitää sopivana saamaan haltuunsa lapsilisää. Äärimmäisessä tapauksessa lautakunta voi itse ottaa haltuunsa lapsilisän ja käyttää sen lapsen parhaaksi.

Lapsilisän suoritustiheyteen nähden sekä Norjassa että Ruotsissa asetuttiin sille kannalle, että lapsilisä on maksettava n e ljännesvuosittain, koska kuukauden väliaika tekisi järjestelmän kankeaksi ja työlääksi ja puolivuotinen järjestelmä taas aiheuttaisi vaaran, että lapsilisä helposti käytettäisiin muihin tarkoituksiin kuin lapsen hyväksi. Norjassa lisä päätettiin suorittaa päivän tarkkuudella syntymäpäivästä alkaen siihen päivään saakka, jona lapsi täyttää 16 vuotta tai kuolee, Ruotsissa taas ensimmäisen kerran siltä vuosineljännekseltä, joka seuraa lapsen syntymää, ja viimeisen kerran siltä neljännekseltä, jonka kuluessa lapsi tulee 16 -vuotiaaksi tai kuolee. Komitean ehdotus, että maksusuoritukset alkaisivat vasta syntymän jälkeisenä vuonna, havaittiin epäkäytännölliseksi, koska vanhemmat silloin joutuisivat odottamaan lapsilisän maksun alkamista huomattavassa määrässä eri pituisen ajan riippuen siitä, minä aikana vuodesta heidän lapsensa olisi syntynyt. Komitea oli perustellut tällaista ehdotustaan sillä, että äitiysavustus korvaa lapsen ensimmäiset vanhemmille tuottamat menot.

\section{Kirjallisuusviitteitä.}

1 Carr-Saunders, A., Världens befolkning, Tukholma 1938, s. 136, liitetaulu. - Nieminen, Armas, Väestökysymys entisinä aikoina ja nykyään, Porvoo ja Helsinki 1941, s. 80.

2 Väestöpolitiikan kehityksestä Ruotsissa ks. Myrdal, Alva, Folk och familj, Tukholma 1945, Cederwall, Gustav, Befolkningsutredningens arbete 1941-1946, Social årsbok 1947, Tukholma, ss. 119-143 ja Gille, H., Recent Developments in Swedish Population Policy, Population Studies (Cambridge) II (1948), ss. $3-70,129-184$.

3 Betänkande om barnkostnadernas fördelning med förslag angående allmänna barnbidrag m.m., Statens offentliga utredningar (SOU), Tukholma, 1946: 5. - Utkast til lov om barnetrygd med motiver, Oslo 1938 kokoelmassa 
Innstillinger og betenkninger fra kongelige og parlamentariske kommisjoner, departementale komiteer m.m., 1938.

4 Levnadsvillkor och hushållsvanor i städer och industriorter omkring år 1933, Sveriges officiella statistik 1938, Tukholma.

5 Linde, Ebbe, En undersökning över allmänna inställningen till befolkningspolitiska åtgärder samt barnbegränsningens orsaker i Göteborg 1942 1945, Betänkande om barnkostnadernas fördelning..., Bilagor, SOU 1946: 6, ss. $5-101$.

6 Myrdal, Alva ja Gunnar, Kris i befolkningsfrågan, Tukholma 1934.

7 Betänkande angående barnbeklädnadsbidrag m.m., SOU 1938: 7, ss. 67 -71. - Slutbetänkande, SOU 1938: 57, ss. 112-115. - Myrdal 1945, ss. 169-187.

8 Elmér, Åke, Svensk socialpolitik, 3 p., Malmö 1948, ss. $160-175$. Toisen väestökomitean julkaisu Den familjevårdande socialpolitiken, SOU 1946: 17 .

- Komitean mietinnöstä annettuja lausuntoja on selostettu Ruotsin hallituksen valtiopäiville antamassa esityksessä laiksi yleisistä lapsilisistä: Kungl. Maj:ts proposition N:o 220 11. 4. 47, Bihang till riksdagens protokoll vid lagtima riksdagen i Stockholm år 1947 I: 13.

${ }_{10}$ Vrt. Myrdal, Alva, Kontanta barnbidrag kräver skärpt steriliseringslag? Tidskrift för barnavård och ungdomskydd (Tukholma) 1946, ss. 55-60. Vrt. myös sama, Folk och familj, ss. 176-178.

II Sosiaaliministeri Möllerin lausunto. Riksdagens protokoll vid lagtima riksmötet år 1947, Första kammaren III: 35, ss. 190-195.

12 Perhepalkkausjärjestelmää oli kritikoitu jo naisten työtä käsitelleen komitean mietinnössä Betänkande angående gift kvinnas förvärvsarbete m.m., SOU 1938: 47, ss. 137-165. - Väestökomitea vetosi myös ulkomailla havaittuun perhepalkkausjärjestelmässä piilevään taipumukseen kehittyä yleiseksi lapsilisäjärjestelmäksi: ks. komitean julkaisua Befolkningspolitik i utlandet, SOU 1944: 26, ss. 75-95. - Myönteisesti perhepalkkausjärjestelmää arvioi Arrhén, Erik, Behovslön - eller likalön? Ett bidrag till diskussionen i befolkningsfrågan, Tukholma 1939.

is Ks. viite 9 . - Sammansatt stats- och andra lagutskotts utlåtande n:o 4, Bihang till riksd. protok. VI: 3. - Asian käsittelystä täysi-istunnoissa ks. Riksdagens protokoll ... 1947, Första kammaren III: 35, ss. 184-198, Andra kammaren II: 17 , ss. $16-42,44-77$, IV: 36 , ss. $11-34$. Lag om allmänna barnbidrag, Svensk författningssamling (SFS) n:o 529/26. 7. 1947. - Lain soveltamisasetus: SFS n:o 660/25. 8. 1947.

14 SFS n:ot 530-531/26. 7. 1947.

15 Lapsilisäjärjestelmän kehityksestä Norjassa ks. paitsi viitteessä ${ }^{3}$ mainittua lapsilisäkomitean mietintöä, Ruotsin väestökomitean julkaisua Befolkningspolitik i utlandet, SOU 1944: 26, ss. 108-109. - Doublet, Jacques, Problèmes démographiques en Norvège, Population (Pariisi) 1946, ss. 658 -659 ja Palmström, H., Les allocations familiales, sama, ss. 660-662. - Wiesener, G., Barnetrygd-familietillägg, Sosialt Arbeid (Oslo) 1946, ss. 51-53. - Evers, Kjell T., Den norske ordning av barnetrygden, Svenska stadsförbundets tidskrift (Tukholma) 1947, ss. 55-58. - Norsk Lov om Børnetilskud, Socialt Tidskrift (Kööpenhamina) 1947, ss. 202-204.

${ }_{16} \mathrm{Ks} . \mathrm{mm}$. Norjan sosiaaliministerin Sven Oftedalin 10. 4. 1946 pitämää esitelmää Gjenreisningen av våre sosiale trygdeordninger, Nordisk Försäkringstidskrift (Tukholma) 1946, s. 289.

17 Lov om barnetrygd, Norsk lovtidend (Oslo) 1946: II, ss. 506-509. 
18 Helger, Bengt ja Wigforss, Knut, En undersökning angående barnkostnaderna på grundval av 1933 års hushållsbudgetmaterial, Betänkande om barnkostnadernas fördelning .., Bilagor, SOU 1946: 6, ss. 103-116.

19 von Hofsten, Erland, En undersökning angående levnadsstandardens variation med barnantalet, Betänkande om barnkostnadernas fördelning ... Bilagor, SOU 1946: 6, ss. 117-136.

20 Väestökomitean julkaisu Den familjevårdande socialpolitiken, SOU 1946: 17, s. 109, taulukko 2. Teokseen sisältyy muillakin aloilla suoritettavien avustussummien keskinäistä vertailua.

21 Betänkande med förslag till ändrade grunder för familjebeskattningen, SOU 1943: 3 , s. 121.

${ }_{22}$ Ks. esim. Akerlund, Henrik, Barnbidrag och skattefria barnavdrag, Några principiella och praktiska synpunkter, Svensk tidskrift (Upsala) 1946, ss. $443-449$.

23 Betänkande med förslag till omläggning av den direkta statsbeskattningen samt angående kvarlåtenskapsskatt m.m., SOU 1946: 79, ss. $82-83$, $89-120$.

24 A. I. Andersonin aloite N:o 300 ensimm. kamarissa, Bihang till riksd. protok. III.

25 J. F. Domön ym. aloite N:o 301 ensimm. kamarissa, Bihang till riksd. protok. III, ja $J$. M. Skoglundin ym. aloite N:o 443 toisessa kamarissa, Bihang till riksd. protok. IV: 2 .

26 Kungl. Maj:ts prop. N:o 220, s. 114, Bihang till riksd. protok. I: 13.

э7 Riksdagens protokoll ... 1947, Andra kammaren IV: 36, s. 14.

28 Elmér, mt., ss. 191-193.

29 E. W. Hảstadin ym. aloite N:o 444 toisessa kamarissa, Bihang till riksd. protok. IV: 2 .

so Lapsilisien maksattamista ei Ruotsin väestökomitea yksityiskohtaisesti käsitellyt vielä mietinnössään perhekustannusten jakaantumisesta (SOU 1946: 5), vaan rajoittui tässä julkaisussa vain joihinkin yleisiin periaatteisiin. Tarkemmin asiaa käsittelee komitean mietintö Betänkande om befolkningspolitikens organisation m.m., SOU 1946: 53, ss. 9-14, 20-23, 26. Lisäksi antoivat lausuntonsa lapsilisän maksamisesta erityisesti kutsutut asiantuntijat: Utredning om utbetalningen av barnbidragen, SOU 1946: 89.

31 Tämänmukainen ehdotus tehtiin eri puolueisiin kuuluvien edustajien Harald Anderssonin ym. toiselle kamarille tekemässä aloitteessa n:o 419, Bihang till riksd. protok. IV:2. Kunnille koituvan lisätyömäärän aiheuttamien kustannusten korvaamisesta niille hyväksyttiin valtiopäivillä toivomusaloite. Mainittu aloite sekä talonpoikaisliiton edustajien K. E. Hanssonin ja P. Perssonin aloite N:o 420 toisessa kamarissa, Bihang till riksd. protok. IV: 2 . 